\title{
Characterization and expression of different pituitary adenylate cyclase-activating polypeptide/vasoactive intestinal polypeptide receptors in rat ovarian follicles
}

\author{
Sergio Vaccari ${ }^{*}+$, Stefania Latini ${ }^{*}$, Marzia Barberi, Anna Teti ${ }^{1}$, Mario Stefanini and Rita Canipari \\ Department of Histology and Medical Embryology, University of Rome 'La Sapienza', Via A. Scarpa, 14, 00161 Rome, Italy \\ ${ }^{1}$ Department of Experimental Medicine, University of L'Aquila, Rome, Italy \\ (Requests for offprints should be addressed to R Canipari; Email: rita.canipari@uniromal.it) \\ *(S Vaccari and S Latini contributed equally to this work) \\ ${ }^{\dagger}$ (S Vaccari is now at Division of Reproductive Biology, Department of Obstetrics and Gynecology, Stanford University School of Medicine, 300 Pasteur Drive \\ Stanford, CA 94305-5317, USA)
}

\begin{abstract}
Pituitary adenylate cyclase-activating polypeptide (PACAP) is a bioactive peptide transiently expressed in preovulatory follicles. PACAP acts by interacting with three types of PACAP receptors. PACAP type I receptor $\left(\mathrm{PAC}_{1}-\mathrm{R}\right)$, which binds specifically to both PACAPs and vasoactive intestinal polypeptide (VIP), although with lower affinity, and two VIP receptors, $\mathrm{VPAC}_{1}-\mathrm{R}$ and $\mathrm{VPAC}_{2}-\mathrm{R}$, which bind to PACAP and VIP with equal affinity. In the present study, we showed the expression of all three receptors in whole ovaries obtained from juvenile and gonadotropin-treated immature rats. A more detailed analysis on cells from preovulatory follicles showed that $\mathrm{PAC}_{1}-\mathrm{R}$ and $\mathrm{VPAC}_{2}-\mathrm{R}$ were expressed in granulosa cells, whereas only VIP receptors were expressed in theca/interstitial (TI) cells and fully grown oocytes presented only $\mathrm{PAC}_{1}-\mathrm{R}$. The distribution of the
\end{abstract}

VIP receptors was confirmed by immunofluorescence. HCG treatment induced stimulation of $\mathrm{PAC}_{1}-\mathrm{R}$ in granulosa cells and $\mathrm{VPAC}_{2}-\mathrm{R}$ in $\mathrm{TI}$ cells. The presence of functional PACAP/VIP receptors was also supported by metabolic studies. We further evaluated the presence of PACAP and VIP receptors by testing the effect of these peptides on apoptosis in granulosa cells cultured, isolated or in whole follicles. Treatment of follicles with PACAP and VIP dosedependently inhibited apoptosis, while only PACAP significantly inhibited isolated granulosa cells. These results demonstrate a different expression of PACAP/VIP receptors in the various follicle compartments and suggest a possible role for PACAP and VIP on granulosa and TI cells, both during follicle development and ovulation.

Journal of Endocrinology (2006) 191, 287-299

\section{Introduction}

Pituitary adenylate cyclase-activating polypeptide (PACAP), originally isolated from ovine hypothalamus, exists in two forms, PACAP-27 and PACAP-38, which share the same N-terminal 27 amino acids and are derived from tissuespecific proteolytic processing of the 176-amino acid precursor protein (Arimura 1992a). The name reflects their potent stimulation of cAMP production in anterior pituitary cells (Miyata et al. 1989). On the basis of sequence similarity, PACAP belongs to the secretin-glucagon-vasoactive intestinal polypeptide (VIP) family of peptides (Kimura et al. 1990). PACAP and VIP act by binding to three types of G-proteincoupled PACAP/VIP receptors. $\mathrm{PAC}_{1}-\mathrm{R}$ binds specifically to both PACAPs and VIP, although with very low affinity; $\mathrm{VPAC}_{1}-\mathrm{R}$ and $\mathrm{VPAC}_{2}-\mathrm{R}$ bind to PACAP and VIP with equal affinity (Lutz et al. 1993). It has been demonstrated that these three receptors are coupled with the adenylate cyclase pathway, and $\mathrm{PAC}_{1}-\mathrm{R}$ is also coupled with phospholipase $\mathrm{C}$
(PLC) (Spengler et al. 1993). Moreover, as a result of alternative splicing, $\mathrm{PAC}_{1}-\mathrm{R}$ exists in five different splice variant forms, which either contain or lack each of the two alternative exons, named hip and hop (Spengler et al. 1993).

PACAPs, VIP, and their receptors are expressed not only in the central nervous system, but also in various organs and peripheral tissues, such as lung, testis, adrenal gland, and ovary (Gottschall et al. 1990, Arimura 1992a,b), which suggests that they may not play a neuroendocrine role alone. Interestingly, PACAP stimulates various ovarian functions, including steroidogenesis, cAMP accumulation, and plasminogen activator (PA) production in rat granulosa cells (Zhong \& Kasson 1994, Heindel et al. 1996, Apa et al. 2002), accelerates meiotic maturation in cumulus-enclosed rat oocytes (Apa et al. 1997), and inhibits apoptosis in preovulatory follicles (Lee et al. 1999), thus indicating that it plays an important role in the female reproductive system. We have also shown a direct action of PACAP on denuded oocytes (Apa et al. 1997). 
Here, we describe the characterization and the signal transduction pathway of the three PACAP/VIP receptors in the various cellular compartments of the ovarian follicle. We reveal that PACAP receptors are present on the surface of denuded germinal vesicle $(\mathrm{GV})$ oocytes, thus demonstrating a direct action of the peptide on these cells.

\section{Materials and Methods}

\section{Materials}

The materials used in the present study were obtained from the following sources: equine chorionic gonadotropin (eCG) and human chorionic gonadotropin (hCG) from Intervet (Livorno, Italy); $\left[{ }^{125} \mathrm{I}\right] \mathrm{cAMP}$ and $\left[{ }^{3} \mathrm{H}\right]$ inositol-1.4.5-trisphosphate from NEN, Perkin Elmer Life Science (Monza, Italy); PACAP and VIP from Calbiochem (San Diego, CA, USA); PACAP/VIP receptor antagonists PACAP 6-38 (H-2734), and a hybrid of neurotensin (6-11) and VIP (7-28) (H-9935) from Bachem (Bubendorf, Swisse); Mebstain Apoptosis Kit Direct from MBL International (Woburn, MA, USA); the antibodies to $\mathrm{VPAC}_{1} \mathrm{H}-130$ (sc-30019) and $\mathrm{VPAC}_{2} \mathrm{H}-50$ (sc30020) from Santa Cruz Biotechnology (Santa Cruz, CA, USA); Alexa Fluor 488-conjugated goat anti-rabbit $\operatorname{IgG}$ (Molecular Probes, Eugene, OR, USA); Dulbecco's modified Eagle medium (DMEM), minimum essential medium with Earl's salts (MEM), Hank's balanced salt solution and fetal calf serum (FCS) from Gibco (Grand Island, NY, USA); dibutyryl cAMP (dbcAMP), cAMP, VIP receptor antagonist (D-PChloro-Phe6, Leu17)-VIP, and all other reagents from Sigma. Highly purified ovine follicle-stimulating hormone (NIDDKo-FSH-19-SIAFP, BIO) was kindly provided by Dr Parlow (National Hormone and Pituitary Program of the NIH).

\section{Animals}

Immature female Wistar rats were purchased from Charles River (Como, Italy). They were housed in groups, maintained in controlled temperature $\left(25^{\circ} \mathrm{C}\right)$ and light $(12 \mathrm{~h} \mathrm{light} /$ day $)$ conditions, and given a regular supply of food and water and allowed to feed ad libitum. Animals were maintained in accordance with the NIH Guide for Care and Use of Laboratory Animals. Experimental protocols were approved by the University 'La Sapienza' Committee for Animal Care and Use. Animals aged from 3 to 25 days were killed by cervical dislocation and the ovaries collected for further analysis. Twenty-five-day-old rats were either killed ( $T_{0}$, untreated rats) or injected subcutaneously with $10 \mathrm{IU}$ eCG. After $48 \mathrm{~h}$, the latter group was either killed (eCG-rats) or injected with $10 \mathrm{IU}$ hCG (hCG-rats) and killed after $6 \mathrm{~h}$ by cervical dislocation.

\section{Granulosa and theca/interstitial cell cultures}

Granulosa cell cultures were prepared from eCG-treated rats as previously described (Canipari \& Strickland 1985). Briefly, the largest follicles from each ovary were punctured with a 25-gauge needle under stereomicroscope and gently pressed to release the granulosa cells. These cells were collected and cultured at a density $1.5 \times 10^{5} / 200 \mu \mathrm{l}$ in MEM supplemented with $0 \cdot 1 \%$ BSA, $2 \mathrm{mM}$ glutamine and antibiotics $(100 \mathrm{mM}$ penicillin and $100 \mu \mathrm{g} / \mathrm{ml}$ streptomycin). Viability was estimated by the trypan blue dye exclusion method.

According to the procedure of Hwang et al. (1996), with minor modifications, theca/interstitial (TI) cells were obtained by digestion of the residual ovarian tissues from untreated rats, after granulosa cell isolation. Briefly, the residuals of the largest follicles were cut into small pieces, washed, and digested with collagenase in a two-step procedure. To obtain TI cells, the tissue was first digested in DMEM containing collagenase $(1 \mathrm{mg} / \mathrm{ml})$ and DNase $(0.5 \mu \mathrm{g} / \mathrm{ml})$ at $37^{\circ} \mathrm{C}$ for $30 \mathrm{~min}$ in order to eliminate the adhering granulosa cells, then washed and digested in DMEM containing $4 \mathrm{mg} / \mathrm{ml}$ collagenase and $0.5 \mu \mathrm{g} / \mathrm{ml}$ DNase for $45 \mathrm{~min}$ at $37^{\circ} \mathrm{C}$. The cells were plated in growth medium (DMEM supplemented with 10\% FCS, $5 \mathrm{mM}$ glutamine, and antibiotics) at a density $2 \times 10^{5}$ cells in $6 \mathrm{~cm}$ Petri dishes and incubated until use. Viability was estimated by the trypan blue dye exclusion method. All incubations were carried out at $37^{\circ} \mathrm{C}$ in a $5 \% \mathrm{CO}_{2}$ atmosphere.

Early antral follicles between 320 and $400 \mu \mathrm{m}$ diameter were mechanically dissected from ovaries of 19-day-old rats as previously described (Cecconi et al. 2004). Groups of 25 follicles were incubated on stainless steel grids in aMEM supplemented with $0.3 \% \mathrm{BSA}$ in the absence or presence of increasing concentrations of PACAP or FSH $(100 \mathrm{ng} / \mathrm{ml})$ for $24 \mathrm{~h}$ at $37^{\circ} \mathrm{C}$. In additional experiments follicles were incubated with PACAP and VIP in the presence of $10^{-6} \mathrm{M}$ PACAP and VIP antagonists.

\section{$R N A$ extraction and RT-PCR}

After the animals had been killed, ovaries were removed aseptically, freed from adherent tissues and stored, ready for RNA extraction, at $-80^{\circ} \mathrm{C}$.

Total RNA from whole ovaries, granulosa cells, and TI cells was isolated by the single-step acid guanidinium thiocyanate-phenol-chloroform method (Chomczynski \& Sacchi 1987). The purity and integrity of the RNA were checked spectroscopically and by gel electrophoresis. Total RNA (1-2 $\mu \mathrm{g})$ was reverse transcribed, in a final volume of $20 \mu$, using the SuperScript II kit (Gibco) according to the manufacturer's instructions. The PCRs were carried out using Taq DNA polymerase (Roche) according to the manufacturer's instructions.

For each primer set, the number of cycles for the PCR was chosen in the exponential phase of amplification, using the annealing temperature provided. For each sample, $10 \mu \mathrm{l} \mathrm{PCR}$ product was submitted to electrophoresis on agarose gel $(1.5 \%)$ and stained with ethidium bromide. Amplified products were analysed using AIDA software (Advanced Image Data Analyzer, 2.11) and mRNA levels normalized against the expression of ribosomal protein s16 mRNA. 
Controls for DNA contamination were performed with gene-specific primers on RNA without reverse transcriptase treatment.

The primers used to amplify $\mathrm{PAC}_{1}-\mathrm{R}, \mathrm{VPAC}_{1}-\mathrm{R}, \mathrm{VPAC}_{2}-\mathrm{R}$, the ribosomal protein $\mathrm{S} 16$ (S16), and the follicle-stimulating hormone receptor (FSH-R) are shown in Table 1. Primers for $\mathrm{PAC}_{1}-\mathrm{R}$ were chosen in a region that allowed the detection of all splice variants.

\section{RT-PCR on single oocytes}

According to the method of Fiorenza \& Mangia (1998), mRNA from rat oocytes was amplified by PCR with slight modifications. Briefly, GV oocytes, obtained by puncturing ovarian follicles of eCG-treated rats, were mechanically isolated from the surrounding cumulus cells and either immediately lysed for RNA extraction or allowed to mature for $6 \mathrm{~h}$ in DMEM supplemented with $0.23 \mathrm{mM}$ sodium pyruvate and 5\% FCS (Met I-oocytes), then treated for RNA isolation. Ovulated metaphase II-oocytes (Met II) were obtained from the oviducts of eCG-hCG-primed animals, $15 \mathrm{~h}$ after hCG injection. The oocytes were freed from cumulus cells (CCs) by hyaluronidase treatment.

In order to remove the zona pellucida (ZP), the oocytes were incubated at room temperature for 1-2 $\mathrm{min}$ in proteinfree Hepes-buffered medium M2 (Quinn et al. 1982) containing 0.5\% Pronase E (Sigma) (Canipari et al. 1988). Groups of five oocytes were transferred to a $0.5 \mathrm{ml}$ tube containing $2 \mu \mathrm{l} \mathrm{H}_{2} \mathrm{O}$ supplemented with $1 \mathrm{U} / \mu \mathrm{l}$ RNasin Ribonuclease Inhibitor (Promega). Tubes were rapidly frozen on dry ice and stored at $-80^{\circ} \mathrm{C}$ until used. Immediately before the assay, the oocytes were diluted by adding $2 \mu \mathrm{l}$ diethylpyrocarbonate (DEPC)-treated water. Total RNA was extracted by rapidly thawing and freezing the tube twice. The lysate was then digested with $40 \mathrm{U} / \mathrm{ml}$ RNase-free bovine pancreatic DNase I at $37^{\circ} \mathrm{C}$ for $7 \mathrm{~min}$ to eliminate the genomic DNA, then heated at $65^{\circ} \mathrm{C}$ for $5 \mathrm{~min}$ to inactivate the DNase I and denature the RNA. Total RNA was reverse transcribed using the Sensiscript Reverse Transcriptase Kit (Qiagen S.p.a., GnbH, Germany), according to the manufacturer's instructions. Controls were performed by omitting the Sensiscript enzyme during RT. The PCR step was performed by adding 15 pmole of each specific primer and $2.5 \mathrm{U}$ Taq DNA polymerase (Roche) in a final volume of $60 \mu \mathrm{l}$. The primers used to amplify $\mathrm{PAC}_{1}-\mathrm{R}$ and $\mathrm{S} 16$ are shown in Table 2. $\mathrm{VPAC}_{1}-\mathrm{R}$ and $\mathrm{VPAC}_{2}-\mathrm{R}$ were the same as those used for the granulosa and TI cells (Table 1).

\section{Calcium measurement}

Cytoplasmic $\mathrm{Ca}^{2+}$ concentration $\left(\left[\mathrm{Ca}^{2+}\right]_{i}\right)$ was measured by dual wavelength fluorescence of single cells loaded with the $\mathrm{Ca}^{2+}$-sensitive intracellular indicator fura-2-acetoxymethylester (AM), as described by Paniccia et al. (1995), with slight modifications.

Zona-free oocytes, 5-10, washed and transferred to M2 (without BSA) on glass coverslips that had been precoated with concanavalin A (Con A, $0 \cdot 2 \mathrm{mg} / \mathrm{ml}$ in PBS), forming the base of the chamber for the $\mathrm{Ca}^{2+}$ measurement (McGuinness et al. 1996). Oocytes were then loaded with $3 \mu \mathrm{M}$ fura-2/AM in serum-free, but otherwise complete, MEM at $37^{\circ} \mathrm{C}$ in $5 \% \mathrm{CO}_{2}$ for $60 \mathrm{~min}$. Coverslips were then rinsed twice with Krebs-Henseleit-Hepes buffer (KHH: $140 \cdot 7 \mathrm{mM} \mathrm{Na}^{+}, 5 \cdot 3 \mathrm{mM} \mathrm{K}^{+}, 132.4 \mathrm{mM} \mathrm{Cl}^{-}$, $0.98 \mathrm{mM} \mathrm{PO}_{4}^{2-}, 1 \cdot 25 \mathrm{mM} \mathrm{Ca}^{2+}, 0 \cdot 81 \mathrm{mM} \mathrm{Mg}^{2+}, 20 \cdot 3 \mathrm{mM}$ HEPES, and $5.5 \mathrm{mM}$ glucose). $\left[\mathrm{Ca}^{2+}\right]_{i}$-dependent fluorescence was measured by means of an AR-CM microfluorimeter (Spex Industries, Edison, NJ, USA) connected with a Diaphot TMD inverted microscope equipped with a CF $\times 40$ fluor objective (Nikon Corp., Tokyo, Japan). Recordings were performed at 340 and $380 \mathrm{~nm}$ excitation wavelengths. Emission, collected by a photomultiplier carrying a $510 \mathrm{~nm}$ cut-off filter, from 340 to $380 \mathrm{~nm}$ and a real-time $340: 380 \mathrm{~nm}$ ratio was recorded by an ASEM Desk 2010 computer (ASEM S.p.A., Buia, Italy). Calibration of the signal was obtained at the end of each experiment by maximally increasing intracellular $\mathrm{Ca}^{2+}$ dependent fura-2 fluorescence with $5 \mu \mathrm{M} \mathrm{Ca}^{2+}$-ionophore ionomycin, followed by the recording of minimal fluorescence after the addition of $7.5 \mathrm{mM}$ EGTA and $60 \mathrm{mM}$ Tris- $\mathrm{HCl}$, $\mathrm{pH} 10 \cdot 5\left[\mathrm{Ca}^{2+}\right]_{\mathrm{i}}$, was calculated as previously described (Grynkiewicz et al. 1985).

Table 1 Sequence of selected oligonucleotides used as RT-PCR primers

\begin{tabular}{|c|c|c|c|c|}
\hline & Primer & PCR conditions & bp & Gene bank accession number \\
\hline \multicolumn{5}{|l|}{ Gene } \\
\hline \multirow[t]{2}{*}{$P A C_{1}-R$} & Fw 5'-GGACCСТTCTCAGCCTGT-3' & $94{ }^{\circ} \mathrm{C} 30 \mathrm{~s}, 60^{\circ} \mathrm{C}$ & 343 & Z23279 \\
\hline & Rw 5'-CACATGATCCGGTCTTGA-3' & $1 \mathrm{~min}, 72^{\circ} \mathrm{C} 1 \mathrm{~min}$ & & \\
\hline$V P A C_{1}-R$ & Fw 5'-TCCGAGCGGAAGTACTTCTG-3' & $94^{\circ} \mathrm{C} 30 \mathrm{~s}, 57^{\circ} \mathrm{C} 45 \mathrm{~s}$, & 359 & NM012685 \\
\hline$V P A C_{2}-R$ & $\begin{array}{l}\text { Fw 5'-CACTAGTGATGGGTGGTCGG-3' } \\
\text { Rw 5'-GCCAGTAGAAGTTCGCCATG-3' }\end{array}$ & $\begin{array}{l}94^{\circ} \mathrm{C} 30 \mathrm{~s}, 57^{\circ} \mathrm{C} 45 \mathrm{~s}, \\
72{ }^{\circ} \mathrm{C} 30 \mathrm{~s}\end{array}$ & 399 & Z25885 \\
\hline FSHR & $\begin{array}{l}\text { Fw 5'-CTTGTCGACCTGGATTTGGAGACCTG-3' } \\
\text { Rw 5' } 5^{\prime} \text {-CTTGAGCTCCTTAATGCCTGTGTTGG-3' }\end{array}$ & $\begin{array}{l}94^{\circ} \mathrm{C} 30 \mathrm{~s}, 60{ }^{\circ} \mathrm{C} 45 \mathrm{~s}, \\
72^{\circ} \mathrm{C} 30 \mathrm{~s}\end{array}$ & 209 & L02842 \\
\hline$S 16$ & $\begin{array}{l}\text { Fw 5'-CGTTCACCTTGATGAGCCCATT-3' } \\
\text { Rw 5'-TCCAAGGGTCCGCTGCAGTC-3' }\end{array}$ & $\begin{array}{l}94^{\circ} \mathrm{C} 30 \mathrm{~s}, 60{ }^{\circ} \mathrm{C} 30 \mathrm{~s}, \\
72{ }^{\circ} \mathrm{C} 30 \mathrm{~s}\end{array}$ & 117 & X17665 \\
\hline
\end{tabular}

Fw, forward primer; Rw, reverse primer. 
Table 2 Sequence of selected oligonucleotides used as RT-PCR primers

Primer

$\begin{array}{ll}\begin{array}{l}\text { Gene } \\ P A C_{1}-R\end{array} & \text { Fw 5'-CAGCACTTCCCTCGCCACCC-3' } \\ & \text { Rw 5'-GGTGTCCCCCAGCCGATGATG-3' } \\ \text { S16 } & \text { Fw 5'-AGGAGAGATTTGCTGGTGTGGA-3' } \\ & \text { Rw 5'-AGCTTTTGAGATAGACTGCCGG-3' }\end{array}$

PCR conditions

$\begin{array}{llll}94{ }^{\circ} \mathrm{C} 30 \mathrm{~s}, 55^{\circ} \mathrm{C} 30 \mathrm{~s}, 72{ }^{\circ} \mathrm{C} 45 \mathrm{~s} & 348 & \text { Z23279 } \\ 94{ }^{\circ} \mathrm{C} 30 \mathrm{~s}, 55^{\circ} \mathrm{C} 30 \mathrm{~s}, 72{ }^{\circ} \mathrm{C} 45 \mathrm{~s} & 95 & \text { M11408 }\end{array}$

$\mathrm{Fw}$, forward primer; $\mathrm{Rw}$, reverse primer.

Assay of $c A M P$

Cultured TI cells were incubated for $1 \mathrm{~h}$ in serum-free medium and then for $2 \mathrm{~h}$ in the presence of various hormones. At the end of the incubation period, the samples were processed as previously described (Apa et al. 1997), with slight modifications. Stimulation was stopped by means of ice-cold $10 \%$ trichloroacetic acid (TCA), and the cells were scraped and sonicated twice for $5 \mathrm{~s}$ at $5 \mathrm{~W}$. The lysate was centrifuged and the supernatant extracted thrice with two volumes of watersaturated diethyl ether. The amount of cAMP was measured by RIA (Steiner et al. 1972). Samples were acetylated before the assay, according to the procedure of Harper \& Brooker (1975). The RIA had a sensitivity of 2-4 fmol cAMP, an intraassay coefficient of variation of $5 \%$, and an interassay coefficient of variation of $10 \cdot 3 \%$. The standard curve was calculated using a $\log$-linear curve fit with $\% \mathrm{~B} / \mathrm{B}_{0}$ ( $y$-axis) against cAMP. The values were normalized to the milligrams of proteins present in the sample. Protein content was measured by the method of Lowry et al. (1951) using BSA as standard.

\section{Phosphoinositide turnover}

In order to measure phosphoinositide degradation, TI and granulosa cells were incubated for $48 \mathrm{~h}$ with $4 \mu \mathrm{Ci} / \mathrm{ml}$ myo$\left[2-\mathrm{H}^{3}\right]$ inositol in DMEM supplemented with 5\% FBS. After labeling, cells were rinsed thrice with Hank's balanced salt solution and preincubated for $20 \mathrm{~min}$ with $20 \mathrm{mM} \mathrm{LiCl}$. PACAP and VIP treatment were started a few minutes after $\mathrm{LiCl}$ addition, and stopped $30 \mathrm{~min}$ later by rapidly placing the culture plates on ice and replacing the medium with ice-cold $10 \%$ TCA. TCA was cleared away by extraction with 1 volume trichlorotrifluoroethane and trioctilamine $(3: 1)$. The samples were separated by ion exchange chromatography on Dowex 1×8-200 (Sigma) and eluted with ammonium phormiate solution at different concentrations. Samples were counted using a $\beta$-counter (Beckman Coulter, Inc., NY, USA).

\section{Immunofluorescence}

Frozen sections $(7 \mu \mathrm{m})$ obtained from ovaries of 23-day-old rats were mounted on Polysine-TM slides (Menzel-Glaser, Braunschweig, Germany), fixed in 4\% formaldehyde, treated with $10 \%$ normal goat serum to minimize non-specific binding, and incubated for $20 \mathrm{~h}$ at $4{ }^{\circ} \mathrm{C}$ with antibodies to
$\mathrm{VPAC}_{1}-\mathrm{R}(1: 200)$ or VPAC2-R (1:200). The sections were extensively washed with PBS and incubated for $1 \mathrm{~h}$ at room temperature with a goat anti-rabbit IgG (Molecular Probes; 1:1000). As a negative control, the primary antibody was omitted and substituted with rabbit immunoglobulin G. Samples were analyzed using a Zeiss Axioplan fluorescence microscope (Carl Zeiss SpA, Milano, Italy).

\section{Morphological analysis of granulosa cell apoptosis}

Granulosa cell apoptosis was evaluated as previously described (Cecconi et al. 2004). Briefly, early antral follicles were mechanically dissected from 19-day-old untreated rats and cultured as described previously. Granulosa cells were released in the medium immediately before or after $24 \mathrm{~h}$ of follicle culture. Cells from single follicles were fixed for $15 \mathrm{~min}$ in $4 \%$ paraformaldeyhde/PBS and cytocentrifuged onto a glass slide at $200 \mathrm{~g}$ for $10 \mathrm{~min}$. The samples were washed thrice with PBS and the chromatin was stained using the TUNEL (TdTmediated dUTP-X nick end labeling) method according to the manufacturer's instructions (Mebstain Apoptosis Kit Direct, MBL International, Woburn, MA, USA). Apoptotic cells were identified and counted in three or more randomly selected fields with at least 100 cells each.

\section{Statistical analysis}

Data are expressed as the mean \pm s.E.M. from at least three independent experiments. Statistical analysis was performed using ANOVA followed by the Tukey-Kramer test for comparisons of multiple groups or paired Student's $t$-test for comparison of data derived from two groups. Values with $P<0 \cdot 05$ were considered statistically significant.

\section{Results}

Expression of PACAP receptors in the ovary

In order to determine the expression of different PACAP receptors in rat ovary, total RNA was extracted from whole ovaries obtained from untreated, eCG-, and hCG-treated rats. Semi-quantitative RT-PCR ( 25 cycles of amplification) showed the presence of $\mathrm{PAC}_{1}-\mathrm{R}$ in untreated and hCG-treated rats and very low levels in eCG-treated rats, as previously demonstrated (Park et al. 2000), but no signal for the presence of the other two 


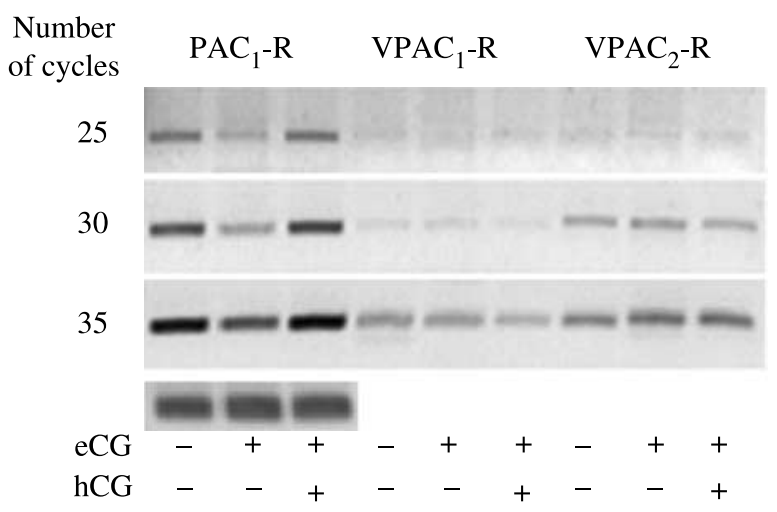

Figure 1 Expression of the different PACAP/VIP receptor subtypes in whole rat ovaries detected by RT-PCR. Total RNA from untreated, eCG-, or hCG-treated immature rat whole ovaries was subjected to RT-PCR for 25, 30, and 35 cycles of amplification using primers specific for $\mathrm{PAC}_{1}-\mathrm{R}, \mathrm{VPAC} \mathrm{C}_{1}-\mathrm{R}, \mathrm{VPAC} \mathrm{C}_{2}-\mathrm{R}$, and $\mathrm{S} 16$ as indicated in the Materials and Methods section. The expression of S16 was used as an internal standard. An aliquot of each PCR product was electrophoresed onto $1.5 \%$ agarose gel and stained with ethidium bromide. No signal was detected in the negative controls for either set of primers. The figure is representative of three independent experiments carried out with independent animals.

receptors (Fig. 1). Positive signals for $\mathrm{VPAC}_{1}-\mathrm{R}$ and $\mathrm{VPAC}_{2}-\mathrm{R}$ were observed only after increasing cycles of amplification, thus suggesting a lower level of expression for these two genes. $\mathrm{VPAC}_{2}-\mathrm{R}$ was evidenced after 30 cycles and apparently not modulated by gonadotropin treatment (Fig. 1). $\mathrm{VPAC}_{1}-\mathrm{R}$ was seen only after 35 cycles and decreased slightly after gonadotropin stimulation (Fig. 1).

In order to investigate the expression of the three receptors in the different ovarian compartments, semi-quantitative RT-PCR experiments were performed on isolated granulosa and TI cells obtained from ovaries of eCG- and hCG-treated rats. A positive signal for $\mathrm{PAC}_{1}-\mathrm{R}$ was observed in granulosa cells, after 25 cycles of amplification, and was stimulated by hCG (Fig. 2). This receptor was not observed in TI cells also at 35 cycles of amplification (data not shown). Positive signals for VIP receptors were observed after further amplification confirming lower levels of expression. $\mathrm{VPAC}_{1}-\mathrm{R}$ was observed only in $\mathrm{TI}$ cells, and $\mathrm{VPAC}_{2}-\mathrm{R}$ was observed in both granulosa and TI cells; $\mathrm{VPAC}_{2}-\mathrm{R}$ was slightly stimulated by hCG in TI cells (Fig. 2).

The close proximity of granulosa and TI cells in the ovarian follicle makes it difficult to separate these cellular types. To exclude contamination by granulosa cells in TI cell preparations and to validate the expression of $\mathrm{VPAC}_{1}-\mathrm{R}$ in the TI, but not in the granulosa cells, we performed similar experiments on enzymatically isolated TI cells. We first investigated the expression of FSH-R, which is expected to be present in granulosa cells but not in TI cells. In granulosa cells from eCG- and hCG-treated rats, mRNA encoding FSH-R was present (Fig. 3). A faint band was also present in TI cells obtained by means of mechanical dissociation of the follicles and was presumably due to granulosa cell contamination. FSH-R mRNA was not expressed in in vitro cultured
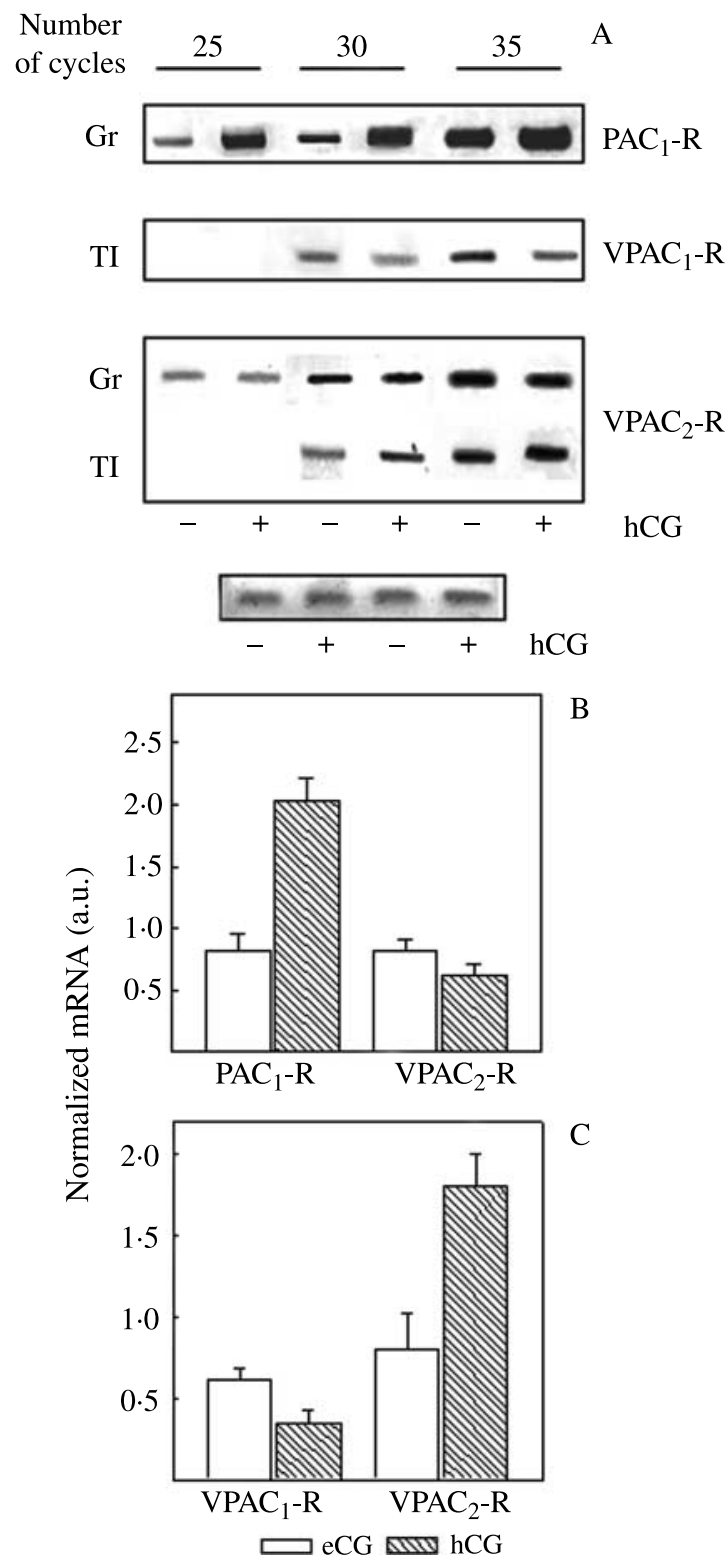

Figure 2 Expression of the different PACAP/VIP receptor subtypes in isolated rat granulosa and theca/interstitial cells detected by RT-PCR. (A) Granulosa (Gr) and theca/interstitial (TI) cells were obtained from ovaries of eCG- and hCG-treated immature rats. Equal amount of total RNA extracted from the cells was subjected to RT-PCR. Specific primers for $\mathrm{PAC}_{1}-\mathrm{R}, \mathrm{VPAC} \mathrm{C}_{1}-\mathrm{R} V \mathrm{PAC}_{2}-\mathrm{R}$, and $\mathrm{S} 16$ were used for different cycles of amplification. The expression of $\mathrm{S} 16$ was used as an internal standard. The bands obtained after 30 cycles of amplification were analyzed with a chemioluminescence detection system (Raytest). PACAP/VIP receptor values were normalized by their respective $S 16$ values and represent the mean \pm S.E.M. of three to five independent experiments carried out with independent animals. (B) granulosa cells, and (C) TI cells. a.u., arbitrary units. ${ }^{*} P<0.005$ vs respective eCG. 


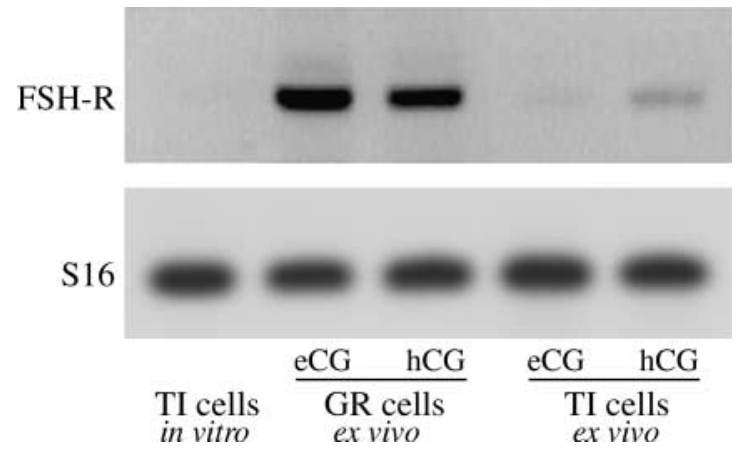

Figure 3 Expression of FSH receptors in granulosa and theca/interstitial cells. Granulosa (GR) and theca/interstitial (TI) cells were obtained as described in Fig. 2. In vitro cultured TI cells (TI in vitro) were obtained from the residuals of the largest follicles after granulosa cells had been isolated from ovaries of 25-day-old untreated rats. Total RNA was extracted and subjected to RT-PCR for 30 cycles of amplification. The figure is representative of the three independent experiments carried out with independent animals.

TI cells, suggesting the absence or very low contamination by granulosa cells (Fig. 3). As already observed in ex vivo TI cell preparations after 35 cycles of amplification, a positive signal for $\mathrm{VPAC}_{1}-\mathrm{R}$ and $\mathrm{VPAC}_{2}-\mathrm{R}$ was identified in cultured $\mathrm{TI}$ cells, although none was present for $\mathrm{PAC}_{1}-\mathrm{R}$. $\mathrm{VPAC}_{2}-\mathrm{R}$ was the predominant form in TI cells (Fig. 4).

In order to investigate the developmental changes in the expression of the three different receptors, RT-PCR was performed on total RNA extracted from whole ovaries obtained from rats of different ages. As shown in Fig. 5, all the receptors were expressed in 3-day-old rats although higher numbers of cycles of amplification were needed to detect VIP receptors suggesting lower level of expression for these two genes also in immature ovaries. $\mathrm{PAC}_{1}-\mathrm{R}$ markedly increased after the 12 th day of age (Fig. $5 \mathrm{~A}), \mathrm{VPAC}_{1}-\mathrm{R}$ significantly

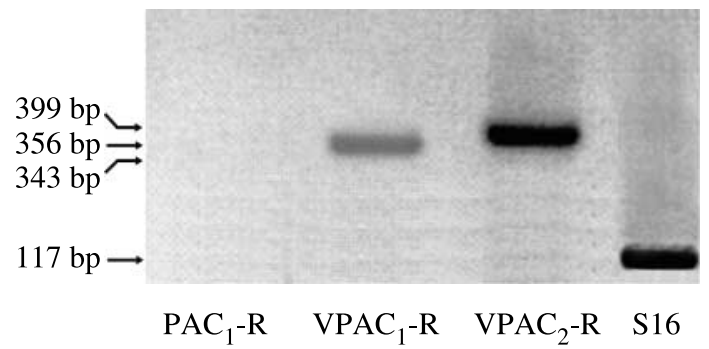

Figure 4 Expression of different molecular forms of PACAP/VIP receptor subtypes as detected by RT-PCR in cultured theca/interstitial cells. Total RNA was subjected to RT-PCR for 35 cycles of amplification using primers specific for $P C_{1}-R, V P A C_{1}-R, V P A C_{2}-R$, and S16, as indicated in the Materials and Methods section. An aliquot of each PCR product and DNA molecular weight markers (Promega 100 bp DNA ladder) were electrophoresed onto 1.5\% agarose gel and stained with ethidium bromide. No signal was detected in the negative control for either set of primers. The figure is representative of four independent experiments carried out with independent animals.
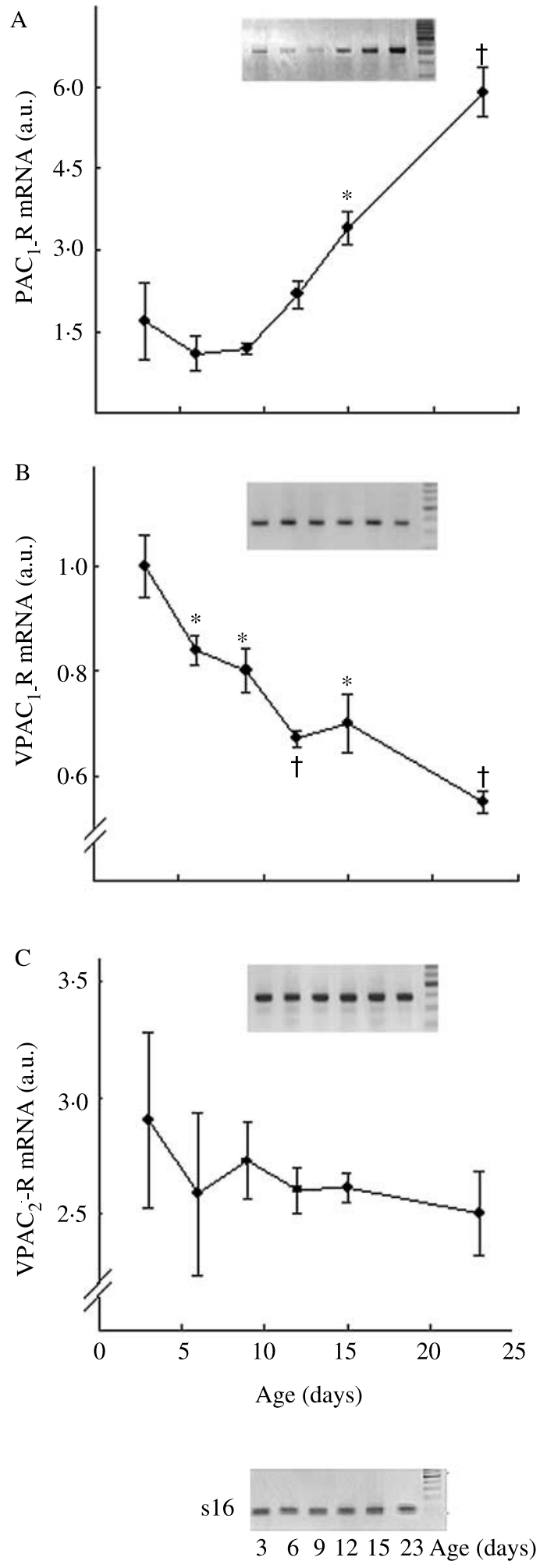

www.endocrinology-journals.org 
decreased with increasing age (Fig. 5B), while $\mathrm{VPAC}_{2}-\mathrm{R}$ remained constant through time (Fig. 5C).

\section{Immunolocalization of PACAP/VIP receptors}

To localize the VIP receptors, immunofluorescence analysis was performed on ovarian sections obtained from 23-day-old rats. The results showed that $\mathrm{VPAC}_{1}-\mathrm{R}$ was predominantly found in association with the blood vessel wall and in the stroma near follicles (Fig. 6). We observed a strong immunoreactivity at the level of the ovarian hilus (Fig. 6A), where the ovarian arteries enter the ovary (Hossain \& O'Shea 1983). Consistent with mRNA expression pattern, $\mathrm{VPAC}_{2}-\mathrm{R}$ was detected ubiquitously in the ovary (Fig. 7) and, as already shown (Bajo et al. 2000), a positive signal was observed in the oviduct (Fig. 7A).

\section{Expression of PACAP receptors in fully grown oocytes}

As previously shown (Apa et al. 2002), PACAP was able to act directly on denuded oocytes, delaying meiotic maturation by modulating their intracellular cAMP levels. Therefore, we investigated oocytes for the expression of PACAP receptors. In order to eliminate any possible contamination by granulosa cell remnants, the $\mathrm{ZP}$ was first removed from denuded oocytes by pronase treatment (Canipari et al. 1988), then RNA extraction and RT-PCR were performed as described in the Materials and Methods. A positive signal for the expression of $\mathrm{PAC}_{1}-\mathrm{R}$ was detected in $\mathrm{GV}$ oocytes after 40 cycles followed by a second amplification for 30 cycles on an aliquot of the first amplification. No signal was detected for $\mathrm{VPAC}_{1}-\mathrm{R}$ and $\mathrm{VPAC}_{2}-\mathrm{R}$ under the same conditions (Fig. 8). No signal for $\mathrm{PAC}_{1}-\mathrm{R}$ was observed in in vivo matured Met I- and Met II-oocytes (data not shown).

These results are supported, in single zona-free GV oocytes, by the observation of a transient spike of $\left[\mathrm{Ca}^{2+}\right]$ triggered by the addition of $10^{-6} \mathrm{M}$ PACAP, which peaked $150 \mathrm{~s}$ after the stimulus $(427 \pm 28 \mathrm{nM})$, followed by a lower sustained phase $(106 \pm 7 \mathrm{nM})$, which lasted more than $800 \mathrm{~s}$ (Fig. 9). No response was detected, in similar conditions, in Met I- and

Figure 5 Developmental expression of the different receptor subtypes in whole rat ovaries detected by RT-PCR. Total RNA, extracted from whole ovaries obtained from rats at the postnatal age indicated, was subjected to RT-PCR for 27 (A) or 35 (B and C) cycles of amplification using primers specific for $\mathrm{PAC}_{1}-\mathrm{R}, \mathrm{VPAC} \mathrm{C}_{1}-\mathrm{R}$, $V P A C_{2}-R$, and $S 16$, as indicated in the Materials and Methods section. The expression of S16 was used as an internal standard. An aliquot of each PCR product was electrophoresed onto $1.5 \%$ agarose gel and stained with ethidium bromide. The bands obtained after amplification were analyzed with a chemioluminescence detection system (Raytest). PACAP/VIP receptor values are normalized by their respective $S 16$ values and represent the mean \pm S.E.M. of three to four independent experiments carried out with independent animals. The insets are representative RT-PCR. ${ }^{*} P<0 \cdot 05,{ }^{+} P<0 \cdot 001$ vs respective day 3 .
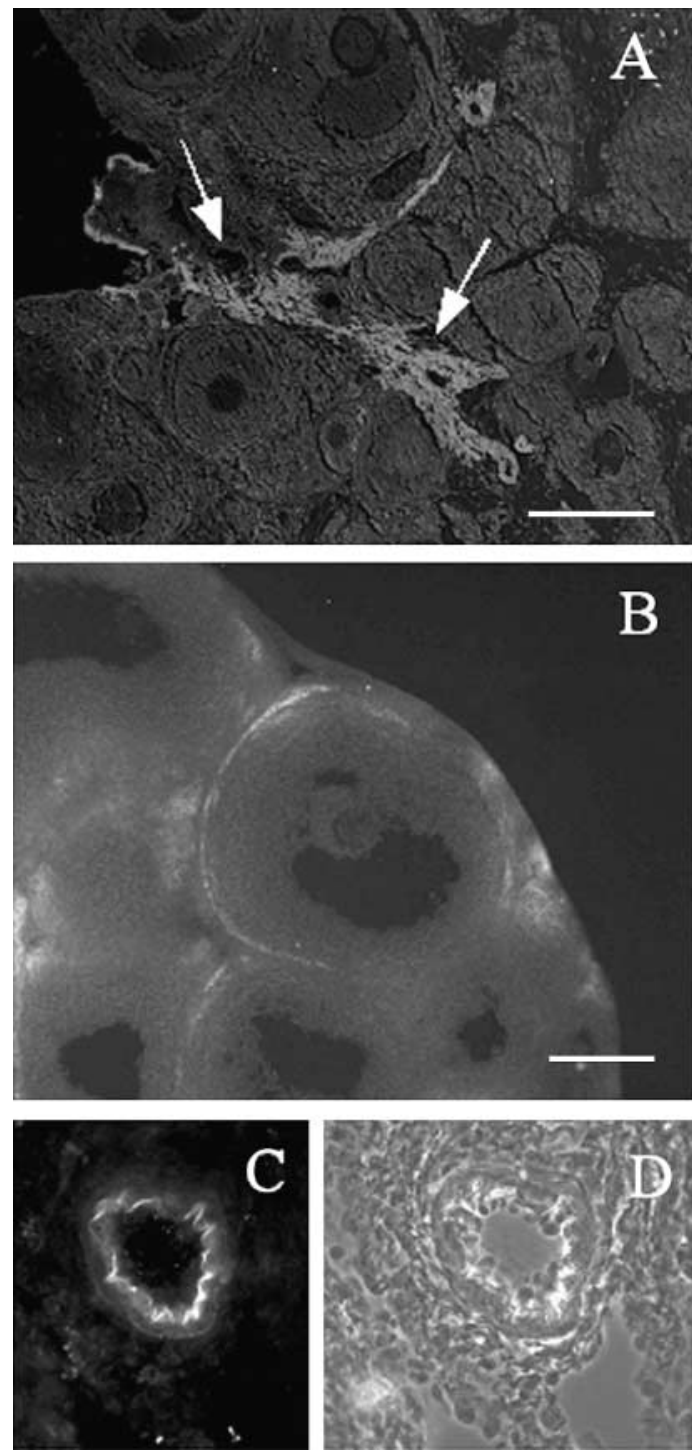

Figure $6 \mathrm{VPAC}_{1}-\mathrm{R}$ immunoreactivity in 23-day-old rat ovaries. (A) Low-power photomicrograph showing immunofluorescence at the ovarian hilus (arrows). (B) Higher magnification showing staining in the stroma near follicles. No positive signal is seen in the granulosa cells. Immunostaining (C) and phase contrast photomicrography (D) of a small ovarian artery. These are representative images of three independent experiments. Scale bar $=100 \mu \mathrm{m}$.

Met II-oocytes (data not shown). This result indicates that functional $\mathrm{PAC}_{1}-\mathrm{Rs}$ are only present on the oocyte surface at the GV stage.

Effect of PACAP and VIP on granulosa and TI cell IPs and cAMP production

In order to determine the signal transduction pathway associated with the activation of PACAP and VIP receptors 

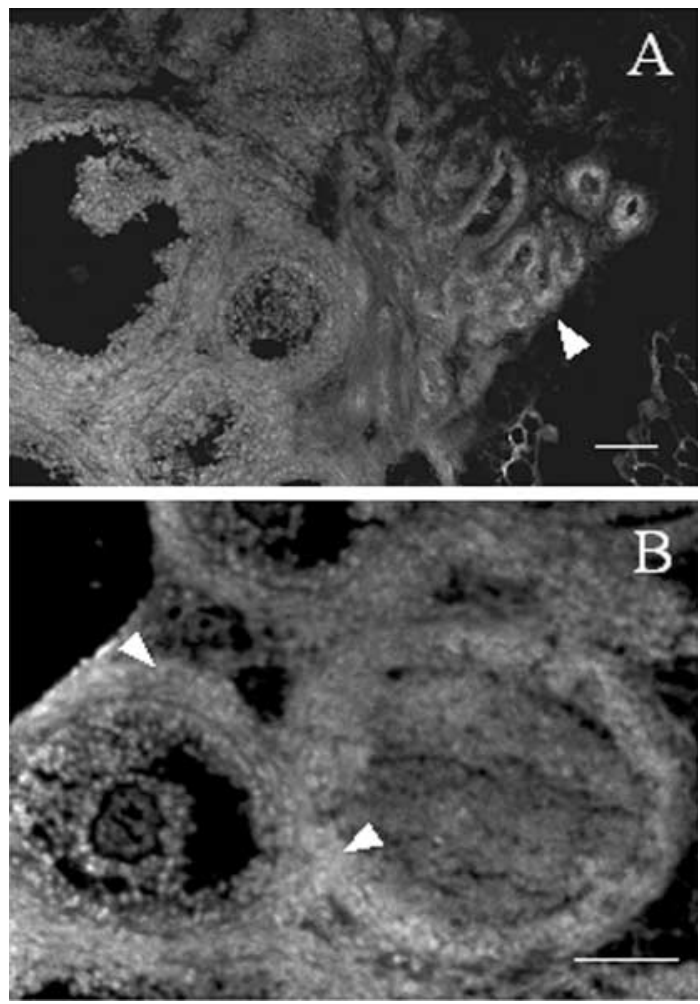

Figure $7 \mathrm{VPAC}_{2}-\mathrm{R}$ immunoreactivity in 23-day-old rat ovaries. (A) Photomicrograph showing distribution of $\mathrm{VPAC}_{2}-\mathrm{R}$. As expected from RT-PCR experiments, this receptor is ubiquitously expressed in the ovary, white arrowhead shows the strong signal in the oviduct. (B) Higher magnification showing a stronger signal in the TI cell compartment (white arrowheads). These are representative images of three independent experiments. Scale bar $=100 \mu \mathrm{m}$.

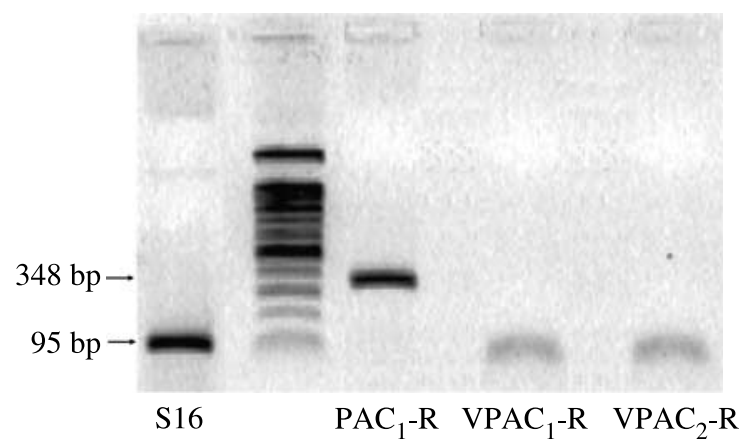

Figure 8 Expression of PACAP receptors in denuded pronasetreated GV oocytes. RT-PCR was conducted as described in the Materials and Methods section. Briefly, S16 was amplified for 35 cycles, while $\mathrm{PAC}_{1}-\mathrm{R}, \mathrm{VPAC} \mathrm{C}_{1}-\mathrm{R}$, and $\mathrm{VPAC}_{2}-\mathrm{R}$ were amplified for 40 cycles followed by a second amplification for 30 cycles on $2 \%$ of the volume obtained in the first amplification. The figure is representative of three independent experiments carried out with independent animals.

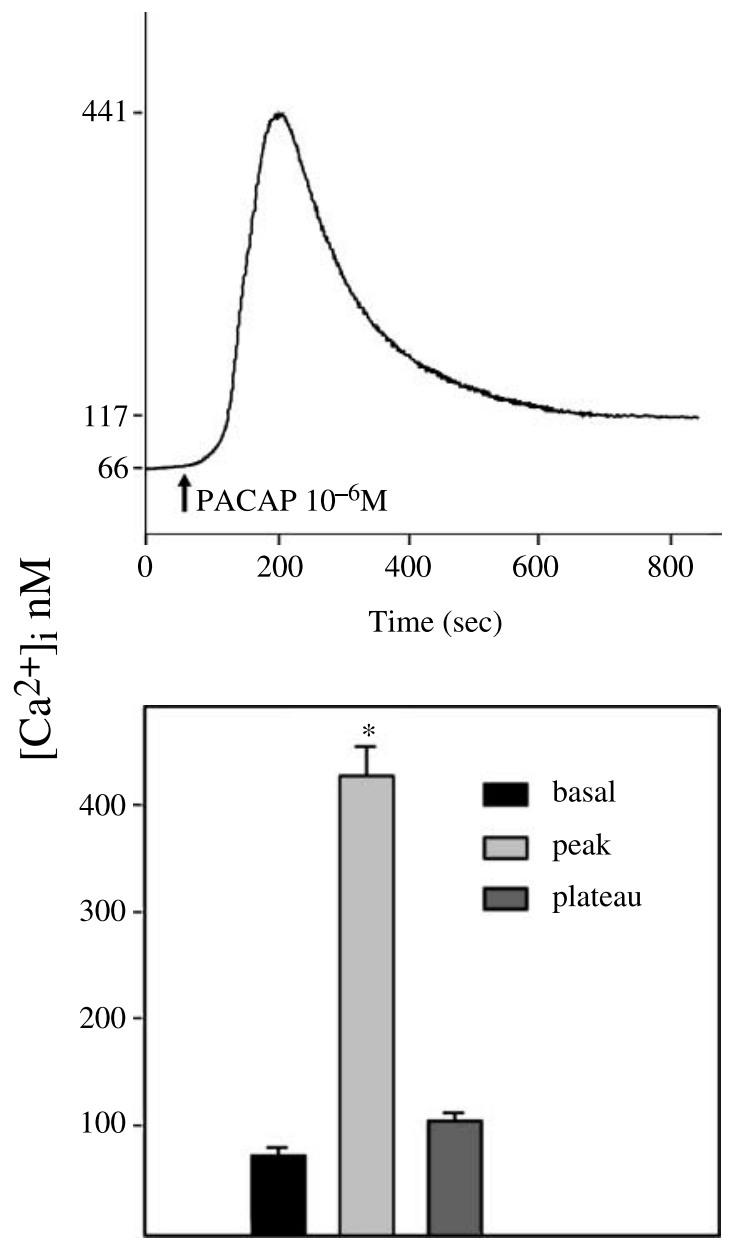

Figure 9 Effect of PACAP on $\left[\mathrm{Ca}^{2+}\right]_{i}$ in a single denuded and zonafree oocyte. The output of a microspectrofluorometer was calibrated as $\left[\mathrm{Ca}^{2+}\right]_{i}$, as described in the Materials and Methods section. Upper panel: representative trace of the effect of $10^{-6} \mathrm{M}$ PACAP on the $\left[\mathrm{Ca}^{2+}\right]_{i}$ of a single oocyte. Lower panel: values represent the mean \pm S.E.M. of $\left[\mathrm{Ca}^{2+}\right]_{i}$ concentration of the spike $(4 \cdot 27 \pm 0 \cdot 28 \mathrm{mM})$, and of the stable, prolonged plateau $(1.06 \pm 0.07 \mathrm{mM})$ obtained in three independent experiments. ${ }^{*} P<0 \cdot 0001$.

present in granulosa and TI cells, we studied the effect of the two peptides on inositol monophosphate $\left(\mathrm{IP}_{1}\right)$, inositol bisphosphate $\left(\mathrm{IP}_{2}\right)$, and inositol trisphosphate $\left(\mathrm{IP}_{3}\right)$ production. Granulosa cells were cultured for $48 \mathrm{~h}$ in the presence of myo- $\left[2-\mathrm{H}^{3}\right]$ inositol, pretreated for $10 \mathrm{~min}$ with $\mathrm{LiCl}$, then stimulated with increasing concentrations of PACAP and VIP. Gonadotropin-releasing hormone $(\mathrm{GnRH})$ was used as a positive control for IP production of granulosa cells (Anderson et al. 1996). Figure 10 shows that both PACAP-38 and PACAP-27 activate PLC, which in turn, catalyses the breakdown of polyphosphoinositides. Treatment with VIP did not significantly affect IP production in these cells, even at high concentrations $\left(10^{-6} \mathrm{M}\right)$. When the same experiment was performed on TI cells, cultured for 

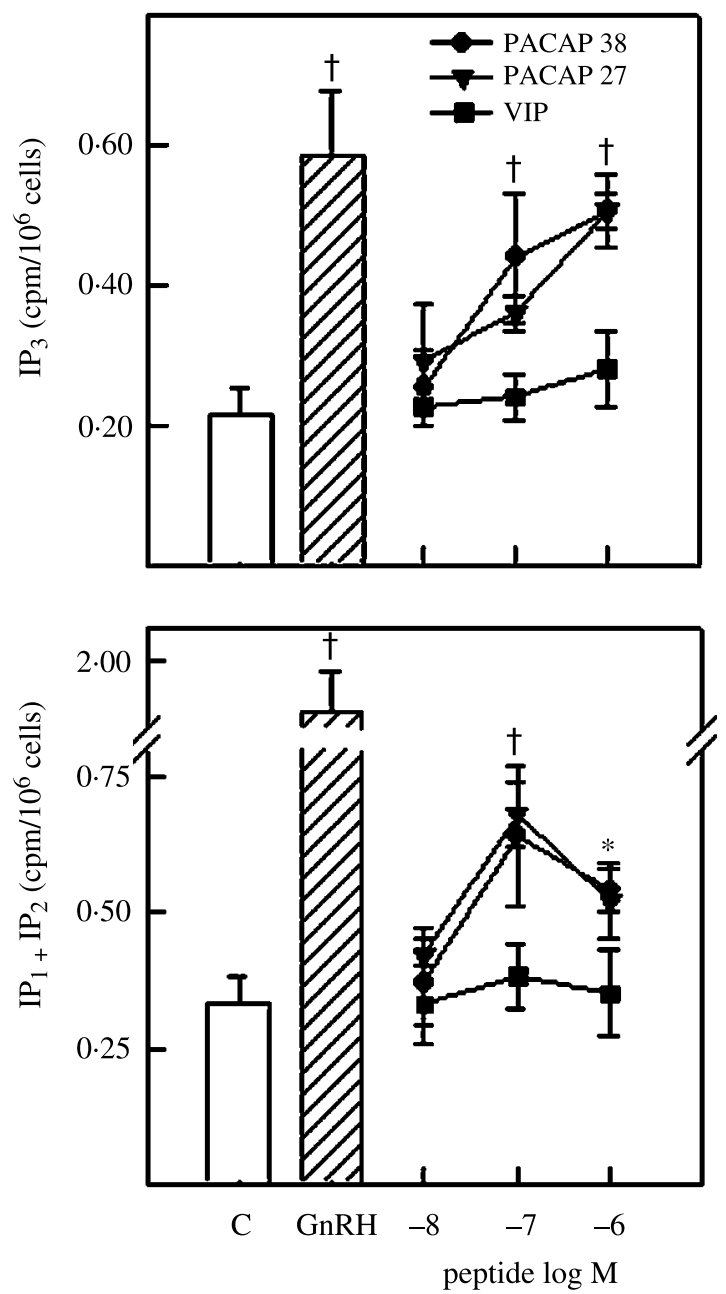

Figure 10 Effect of PACAP stimulation on IP production in granulosa cells. Granulosa cells, prepared as described in the Materials and Methods section, were cultured with $4 \mu \mathrm{Ci}$ myo- $\left[2-\mathrm{H}^{3}\right]$ inositol for $48 \mathrm{~h}$, pre-incubated with $\mathrm{LiCl}$ for $10 \mathrm{~min}$, and stimulated with $10^{-7} \mathrm{M}$ GnRH, with medium alone (C), or with increasing concentrations of PACAP-27, PACAP-38, and VIP. The reaction was interrupted after 30 min of incubation by replacing medium with ice-cold 10\% TCA. Aliquots of all samples were analyzed by ionic-exchange chromatography on Dowex 1 X8-200. The values represent the mean \pm S.E.M. of three independent experiments each performed in duplicate. $* P<0 \cdot 05,{ }^{+} P<0.01$ vs control.

$48 \mathrm{~h}$ in the presence of PACAP and VIP, no effect was detected on IP production (data not shown).

To evaluate whether the action of PACAP and VIP on TI cells was mediated by cAMP production, isolated TI cells were cultured for $2 \mathrm{~h}$ in medium alone (control), FSH (100 ng/ml), hCG $(100 \mathrm{mU} / \mathrm{ml})$, or increasing concentrations of PACAP38 and VIP $\left(10^{-7}\right.$ and $\left.10^{-8} \mathrm{M}\right)$ in the absence of serum. As expected, the addition of hCG significantly increased the levels of cAMP, while that of FSH had no effect. Both PACAP and VIP produced statistically significant increases in cAMP levels (Fig. 11).

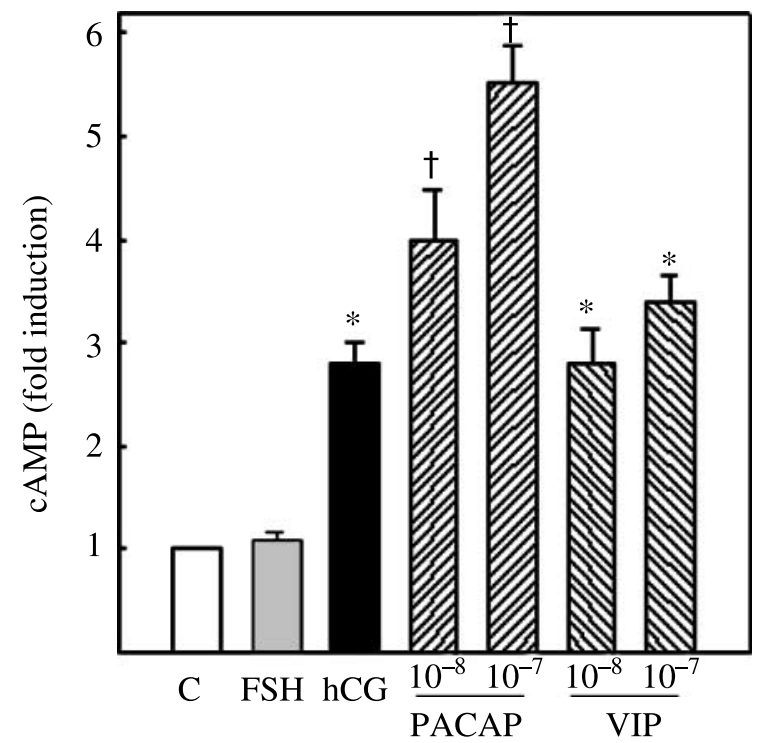

Figure 11 Effect of PACAP and VIP on cAMP production by TI cells. Isolated TI cells, prepared as described in the Materials and Methods section, were cultured for $2 \mathrm{~h}$ in medium alone (control, C), FSH $(100 \mathrm{ng} / \mathrm{ml})$, hCG $(100 \mathrm{mU} / \mathrm{ml})$, or increasing concentrations of PACAP-38 and VIP in the absence of serum. At the end of incubation total CAMP was measured by RIA. The values represent the mean \pm S.E.M. of three independent experiments each performed in duplicate. ${ }^{*} P<0 \cdot 001,{ }^{+} P<0 \cdot 0001$ vs control.

\section{Effect of PACAP and VIP on granulosa cell apoptosis}

In order to evaluate the presence of functional receptors in granulosa or TI cells, we studied the effect of PACAP and VIP on granulosa cell apoptosis. Cells, obtained from 22-day untreated rats, were cultured either isolated or in whole follicles. The presence of apoptotic cells was evaluated in granulosa cells after $24 \mathrm{~h}$ of culture in the presence of $100 \mathrm{ng} / \mathrm{ml} \mathrm{FSH}$, as a positive control, or increasing concentrations of PACAP (from $10^{-9}$ to $10^{-7} \mathrm{M}$ ). To this end granulosa cells were stained with Hoechst 33258 or with TUNEL at the end of culture. Granulosa cells obtained from early antral follicles immediately after isolation did not show detectable signs of apoptosis $(4 \pm 0 \cdot 8 \%)$. In granulosa cells obtained from follicles incubated in serum-free medium for $24 \mathrm{~h}$, apoptosis increased to $22 \cdot 3 \pm 1 \cdot 5 \%$ and PACAP inhibited apoptosis in a dose-dependent manner $(24 \pm 1 \cdot 5$, $17 \pm 1 \cdot 2,12 \pm 0 \cdot 9 \%, 10^{-9}, 10^{-8}$, and $10^{-7}$ respectively) Levels of apoptosis similar to those obtained with FSH (14 \pm $1 \cdot 1 \%$ ) were obtained with $10^{-7} \mathrm{M}$ PACAP. As already shown (Flaws et al. 1995) also VIP inhibited granulosa cell apoptosis when cultured in whole follicles (Fig. 12B) suggesting the presence of VIP receptors in the whole follicles.

In isolated granulosa cells cultured in serum-free medium for $24 \mathrm{~h}$, apoptosis increased to $55 \pm 1 \cdot 7 \%$ and $\mathrm{FSH}$ significantly reduced it to $47 \pm 1 \cdot 5 \%$. PACAP inhibited apoptosis in a dose-dependent manner $(53 \pm 1 \cdot 5,50 \pm 1 \cdot 2$, $46 \pm 1 \cdot 9 \%, 10^{-9}, 10^{-8}$, and $10^{-7}$ respectively), while VIP 

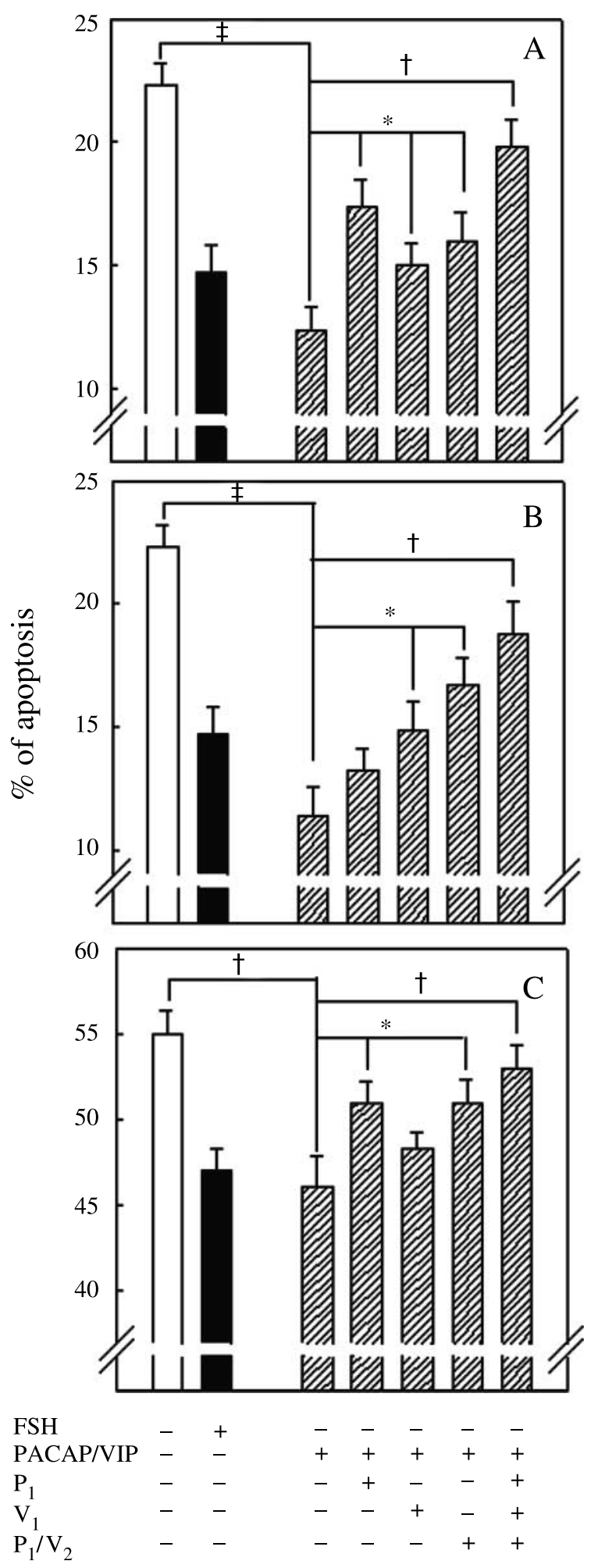

did not show any significant effect (data not shown) confirming the presence of $\mathrm{PAC}_{1}-\mathrm{R}$ and of a low number of VIP receptors in isolated granulosa cells.

To further characterize the contribution of the different receptor subtypes to this inhibitory effect, follicles were incubated with PACAP (Fig. 12A) and VIP (Fig. 12B) in the presence of PACAP/VIP receptor antagonists. The antagonists utilized were: PACAP (6-38) a $\mathrm{PAC}_{1}-\mathrm{R}$, and to a lesser degree $\mathrm{VPAC}_{2}-\mathrm{R}$ selective antagonist (D-P-Chloro-Phe6, Leu17), $\mathrm{VIP}$, a moderately potent $\mathrm{VPAC}_{1}-\mathrm{R}$ antagonist and a hybrid of neurotensin (6-11) and VIP (7-28), a moderately potent $\mathrm{PAC}_{1}-\mathrm{R}$ antagonist and a weak antagonist at $\mathrm{VPAC}_{2}-\mathrm{R}$ (Dickinson et al. 1997). As shown in Fig. 12A, all receptor antagonists significantly reversed PACAP inhibition of apoptosis, while PACAP (6-38) did not inhibit VIP action (Fig. 12B) supporting the presence of all three receptor subtypes in the follicle and the presence of $\mathrm{PAC}_{1}-\mathrm{R}$ predominantly in the GC compartment.

To determine if $\mathrm{PAC}_{1}-\mathrm{R}$ was effectively the predominant form present in granulosa cells, GCs isolated from early antral follicles, were incubated in the same conditions as described for whole follicles. PACAP and FSH prevented apoptosis (Fig. 12C), while VIP had no effect (data not shown). PACAP action was reversed by the addition of PACAP (6-38) and VIP (7-28), while (D-P-Chloro-Phe6, Leu17) VIP had no effect (Fig. 12C). These data are in accordance with the presence of $\mathrm{PAC}_{1}-\mathrm{R}$ and the absence of $\mathrm{VPAC}_{1}-\mathrm{R}$ in GCs. However, we cannot discriminate between the presence of $\mathrm{PAC}_{1}-\mathrm{R}$ and $\mathrm{VPAC}_{2}-\mathrm{R}$ due to the low selectivity of VIP (7-28).

\section{Discussion}

PACAP is known to bind to at least three types of receptors: $\mathrm{PAC}_{1}-\mathrm{R}$, which is specific for PACAP and has a low affinity for VIP, and the two VIP receptors $\mathrm{VPAC}_{1}-\mathrm{R}$ and $\mathrm{VPAC}_{2}-\mathrm{R}$, which bind PACAP and VIP with similar affinities. Reports in the literature on which receptor is found in the ovary are somewhat contrasting. While there is a general agreement on the presence of $\mathrm{PAC}_{1}-\mathrm{R}$, there are some discrepancies regarding VIP receptors. Gras et al. (2000) found only VPAC ${ }_{2}$-R in granulosa cells, whereas Ko \& Park-Sarge (2000) found both $\mathrm{VPAC}_{1}-\mathrm{R}$ and $\mathrm{VPAC}_{2}-\mathrm{R}$. No evidence is yet available on the presence of PACAP/VIP receptors in TI cells.

Figure 12 Percentage of apoptosis in (A) granulosa cells isolated from early antral follicles cultured for $24 \mathrm{~h}$ in the absence of serum or supplemented with FSH $(100 \mathrm{ng} / \mathrm{ml})$ or PACAP $\left(10^{-7} \mathrm{M}\right)$ with or without $10^{-6} \mathrm{MPAC}_{1}$ antagonist PACAP $(6-38)\left(\mathrm{P}_{1}\right)$ or $10^{-6} \mathrm{M} \mathrm{VIP}_{1}$ antagonist $\left(\mathrm{V}_{1}\right)$ or $\mathrm{PAC}_{1} / \mathrm{VIP}_{2}$ antagonist, $\left(\mathrm{P}_{1} / \mathrm{N}_{2}\right)$ or all antagonists together; (B) granulosa cells isolated as shown in (A), but cultured in the presence of VIP $\left(10^{-7} \mathrm{M}\right)$. (C) Granulosa cells isolated from early antral follicles and cultured for $24 \mathrm{~h}$ in the absence of serum or supplemented with FSH $(100 \mathrm{ng} / \mathrm{ml})$ or PACAP $\left(10^{-7} \mathrm{M}\right)$ with or without PACAP/VIP receptor antagonists. Values represent the mean \pm s.E.M. of three to six independent experiments. ${ }^{*} P<0 \cdot 05$, ${ }^{+} P<0 \cdot 01,{ }^{\ddagger} P<0 \cdot 001$. 
We used the RT-PCR approach to determine the expression of PACAP/VIP receptors in the whole ovary. All three forms were found at all ages examined, though in different amounts. We found that the predominant form expressed in the rat ovary is $\mathrm{PAC}_{1}-\mathrm{R}$, while $\mathrm{VPAC}_{1}-\mathrm{R}$ and $\mathrm{VPAC}_{2}-\mathrm{R}$ are less abundant.

In the preovulatory follicles, we analyzed granulosa cells, oocytes, and TI cells separately for the presence of VIP/ PACAP receptors. In accordance with the data published by Gras et al. (2000) in isolated granulosa cells, we observed abundant mRNA transcripts for $\mathrm{PAC}_{1}-\mathrm{R}$, lower levels of mRNA for $\mathrm{VPAC}_{2}-\mathrm{R}$ and no mRNA for $\mathrm{VPAC}_{1}-\mathrm{R}$. $\mathrm{PAC}_{1}-$ $\mathrm{R}$ was the only receptor found to be statistically modulated by gonadotropin.

As far as TI cells are concerned, indeed, we found that $\mathrm{VPAC}_{2}-\mathrm{R}$ and $\mathrm{VPAC}_{1}-\mathrm{R}$ were both expressed in the TI compartment, whereas $\mathrm{PAC}_{1}-\mathrm{R}$ was not. This is in agreement with our previous demonstration that PACAP and VIP are equally effective in stimulating granulosa cells cultured within the whole follicle (Apa et al. 1997, 2002), which thus suggests the presence of VIP receptors in TI cells.

In agreement with functional (Apa et al. 1997) and binding data (Gras et al. 2000) reported in the literature, the present study provides direct evidence of the presence of $\mathrm{PAC}_{1}-\mathrm{R}$ and the absence of VIP receptors on GV oocytes. After having previously shown that PACAP, but not VIP, increases intracellular cAMP levels in denuded GV oocytes (Apa et al. 1997), we now demonstrate that $10^{-6} \mathrm{M}$ PACAP stimulates $\mathrm{Ca}^{++}$mobilization in the same oocytes. These data are consistent with the presence of a functional $\mathrm{PAC}_{1}$ receptor in fully grown GV oocytes. PACAP receptors are already present in primordial germ cells in fetal gonads; moreover, PACAP has been shown to stimulate primordial germ cell proliferation via cAMP production (Pesce et al. 1996) and inhibit meiotic resumption in fully grown oocytes (Apa et al. 1997). However, after resumption of meiotic maturation, we observed a decrease in the levels of mRNA for these receptors, followed by a decrease in the number of functional receptors on the cell surface, as measured by an inability to stimulate $\mathrm{Ca}^{++}$mobilization. Therefore, at the time of PACAP production in preovulatory follicles, $3-6 \mathrm{~h}$ after the LH surge (Gras et al. 1996, Koh et al. 2000), this peptide is no longer able to directly interfere with oocyte maturation.

The presence and the distribution of functional PACAP/VIP receptors in granulosa and TI cells have been supported by metabolic studies. In isolated granulosa cells, PACAP stimulated both cAMP production (Apa et al. 1997) and phosphoinositide (IP) turnover (this paper), while VIP stimulated cAMP production alone at high concentrations in the presence of a phosphodiesterase inhibitor (IBMX) (Apa et al. 1997). These data demonstrate the presence of functional $\mathrm{PAC}_{1}-\mathrm{R}$, the only one associated with the activation of both adenylate cyclase and PLC and of low number of VIP receptors. Conversely, in TI cells both PACAP and VIP stimulated cAMP but not IP breakdown, which is consistent with the presence of VIP receptors and the absence of $\mathrm{PAC}_{1}-\mathrm{R}$.

Furthermore, here we demonstrate that PACAP and VIP both were able to prevent granulosa cell apoptosis in serumfree medium cultured follicles as already shown (Flaws $e t$ al. 1995, Lee et al. 1999), while only PACAP efficiently prevented apoptosis in isolated granulosa cells. These results together with the data obtained with the receptor antagonists further support the presence of functional VIP receptors on TI cells.

However, since TI cells are a very heterogeneous population we characterized VIP receptor localization in this compartment by immunofluorescence. In accordance with RT-PCR data, $\mathrm{VPAC}_{2}-\mathrm{R}$ was ubiquitously found in the ovary, while $\mathrm{VPAC}_{1}-\mathrm{R}$ was found in the proximity of follicles, but not in the GCs. The localization of $\mathrm{VPAC}_{1}-\mathrm{R}$ suggests an association with the smooth muscle cells located in the theca externa (Ko et al. 2006). A strong signal was found also in the blood vessel wall.

VIP has been detected in neonatal rat ovaries as early as 2 days after birth; VIP-containing nerve fibres are present in rat ovaries around blood vessels, as well as around follicles at different stages of development, in close proximity of the theca cell layers and occasionally between primordial follicles (Ahmed et al. 1986). The contemporary presence of VIP and its receptors (this paper) around preantral and antral follicles suggests a possible role of VIP in both growing and preovulatory follicles. Indeed, VIP has been shown to suppress granulosa cell apoptosis, to promote follicle survival in in vitro growing preantral rat follicles (Flaws et al. 1995), and to stimulate ovarian steroidogenesis (Davoren \& Hsueh 1985, Ahmed et al. 1986). Moreover, it has been shown that it exerts a relaxant effect on the rabbit ovarian artery (Jorgensen 1991). Therefore, the localization of VIP and its receptors in association with blood vessels suggests that this neuropeptide might be involved in the regulation of ovarian blood flow. The increased ovarian stromal blood flow may lead to a greater delivery of gonadotropins to the granulosa cells of the developing follicles (Redmer \& Reynolds 1996).

In conclusion, the different pattern of distribution of $\mathrm{PAC}_{1}-\mathrm{R}, \mathrm{VPAC}_{1}-\mathrm{R}$ and $\mathrm{VPAC}_{2}-\mathrm{R}$ suggests distinct functional roles. The presence of VIP receptors around blood vessels, suggests an important role for this peptide in the blood flow regulation. In fact, perifollicular vascular expansion associated with increased rates of blood flow are developmentally important for the generation of a normal follicle and competent oocyte (Van Blerkom 2000).

The temporal and spatial distribution of PACAP, after the luteinizing hormone $(\mathrm{LH})$ surge, suggests that the action of PACAP via $\mathrm{PAC}_{1}-\mathrm{R}$ may be restricted to a specific developmental window. The fact that PACAP has been shown to induce genes related to ovulation and luteinization, and to mediate some of the effects of LH on granulosa cell differentiation at the time of ovulation (Gras et al. 1999, Lee et al. 1999, Park et al. 2000), suggests that PACAP is involved in the preovulatory follicle and that it may serve as an ovarian 
physiological mediator of gonadotropin at the time of the ovulatory process. However, the presence of PACAP around growing follicles in cyclic rats, points to an additional role of this peptide in the regulation of growing follicle development at least in the adult ovary after the first LH surge. Indeed, we have recently demonstrated an inhibitory effect of PACAP on mouse preantral follicle growth and differentiation (Cecconi et al. 2004).

Indeed, activation of follicle development is under the influence of both stimulatory and inhibitory regulation (Skinner 2005). Abnormal regulation of primordial follicle development can affect the reproductive capacity of the female and menopausal onset, as shown in anti-Mullerian hormone null females (Durlinger et al. 1999). Further studies are needed to evaluate the role of PACAP and VIP in ovarian physiology.

\section{Acknowledgements}

We thank Mr S Greci for his excellent technical assistance, Dr A F Parlow and the National Hormone and Pituitary Distribution Program of the NIDDK for providing the ovine FSH and LH, and Mr Lewis Baker for reviewing the English in the manuscript. This work was supported by grants from the MIUR co-fin 2003 to R Canipari and 2005 to M Stefanini; and from the University of Rome 'La Sapienza' 2004 to R Canipari and Department of Health Special Program 2004 to M Stefanini. The authors declare that there is no conflict of interest that would prejudice the impartiality of this scientific work.

\section{References}

Ahmed CE, Dees WL \& Ojeda SR 1986 The immature rat ovary is innervated by vasoactive intestinal peptide (VIP)-containing fibers and responds to VIP with steroid secretion. Endocrinology 118 1682-1689.

Anderson L, Hillier SG, Eidne KA \& Miro F 1996 GnRH-induced calcium mobilisation and inositol phosphate production in immature and mature rat ovarian granulosa cells. Journal of Endocrinology 149 449-456.

Apa R, Lanzone A, Mastrandrea M, Miceli F, Macchione E, Fulghesu AM, Caruso A \& Canipari R 1997 Effect of pituitary adenylate cyclase-activating peptide on meiotic maturation in follicle-enclosed, cumulus-enclosed, and denuded rat oocytes. Biology of Reproduction 57 1074-1079.

Apa R, Lanzone A, Miceli F, Vaccari S, Macchione E, Stefanini M \& Canipari R 2002 Pituitary adenylate cyclase-activating polypeptide modulates plasminogen activator expression in rat granulosa cell. Biology of Reproduction 66 830-835.

Arimura A 1992a Pituitary adenylate cyclase activating polypeptide (PACAP): discovery and current status of research. Regulatory Peptides 37 287-302.

Arimura A 1992b Receptors for pituitary adenylate cyclase-activating polypeptide. TEM $3288-294$.

Bajo AM, Juarranz MG, Valenzuela P, Martinez P, Prieto JC \& Guijarro LG 2000 Expression of vasoactive intestinal peptide (VIP) receptors in human uterus. Peptides 21 1383-1388.

Canipari R \& Strickland S 1985 Plasminogen activator in the rat ovary. Journal of Biological Chemistry $2605121-5125$.

Canipari R, Bevilacqua A, Colonna R, De Felici M \& Mangia F 1988 Actin synthesis is not regulated by granulosa cells in mouse growing and preovulatory oocytes. Gamete Research 20 115-124.
Cecconi S, Rossi G, Barberi M, Scaldaferri L \& Canipari R 2004 Effect of pituitary adenylate cyclase-activating polypeptide and vasoactive intestinal polypeptide on mouse preantral follicle development in vitro. Endocrinology 145 2071-2079.

Chomczynski P \& Sacchi N 1987 Single-step method of RNA isolation by acid guanidinium thiocyanate-phenol-chloroform extraction. Analytical Biochemistry 162 156-159.

Davoren JB \& Hsueh AJW 1985 Vasoactive intestinal peptide: a novel stimulator of steroidogenesis by cultured rat granulosa cells. Biology of Reproduction 33 37-52.

Dickinson T, Fleetwood-Walker SM, Mitchell R \& Lutz EM 1997 Evidence for roles of vasoactive intestinal polypeptide (VIP) and pituitary adenylate cyclase activating polypeptide (PACAP) receptors in modulating the responses of rat dorsal horn neurons to sensory inputs. Neuropeptides $\mathbf{3 1}$ $175-185$.

Durlinger AL, Kramer P, Karels B, de Jong FH, Uilenbroek JT, Grootegoed JA \& Themmen AP 1999 Control of primordial follicle recruitment by antiMullerian hormone in the mouse ovary. Endocrinology 140 5789-5796.

Fiorenza MT \& Mangia F 1998 Quantitative RT-PCR amplification of RNA in single mouse oocytes and preimplantation embryos. Biotechniques $\mathbf{2 4}$ 618-623.

Flaws JA, DeSanti A, Tilly KI, Javid RO, Kugu K, Johnson AL, Hirshfield AN \& Tilly JL 1995 Vasoactive intestinal peptide-mediated suppression of apoptosis in the ovary: potential mechanisms of action and evidence of a conserved antiatretogenic role through evolution. Endocrinology 136 4351-4359.

Gottschall PE, Tatsuno I, Miyata A \& Arimura A 1990 Characterization and distribution of binding sites for the hypothalamic peptide, pituitary adenylate cyclase-activating polypeptide. Endocrinology 127 272-277.

Gras S, Hannibal J, Georg B \& Fahrenkrug J 1996 Transient periovulatory expression of pituitary adenylate cyclase activating peptide in rat ovarian cells. Endocrinology 137 4779-4785.

Gras S, Hannibal J \& Fahrenkrug J 1999 Pituitary adenylate cyclase-activating polypeptide is an auto/paracrine stimulator of acute progesterone accumulation and subsequent luteinization in cultured periovulatory granulosa/lutein cells. Endocrinology 140 2199-2205.

Gras S, Hedetoft C, Pedersen SH \& Fahrenkrug J 2000 Pituitary adenylate cyclase-activating peptide stimulates acute progesterone production in rat granulosa/lutein cells via two receptor subtypes. Biology of Reproduction 63 206-212

Grynkiewicz G, Poenie M \& Tsien RY 1985 A new generation of $\mathrm{Ca}^{2+}$ indicators with greatly improved fluorescence properties. Journal of Biological Chemistry $2603440-3450$.

Harper JF \& Brooker G 1975 Femtomole sensitive radioimmunoassay for cAMP and cGMP after $2^{\prime} 0$-acetylation by acetic anhydride in aqueous solution. Journal of Cyclic Nucleotide Research 1 207-218.

Heindel JJ, Sneeden J, Powell CJ, Davis B \& Culler MD 1996 A novel hypothalamic peptide, pituitary adenylate cyclase-activating peptide, regulates the function of rat granulosa cells in vitro. Biology of Reproduction $\mathbf{5 4}$ 523-530.

Hossain MI \& O'Shea JD 1983 The vascular anatomy of the ovary and the relative contribution of the ovarian and uterine arteries to the blood supply of the ovary in the guinea-pig. Journal of Anatomy 137 457-466.

Hwang JJ, Lin SW, Teng CH, Ke FC \& Lee MT 1996 Relaxin modulates the ovulatory process and increases secretion of different gelatinases from granulosa and theca-interstitial cells in rats. Biology of Reproduction $\mathbf{5 5}$ 1276-1283.

Jorgensen JC 1991 Interaction between norepinephrine, NPY and VIP in the ovarian artery. Peptides 12 831-837.

Kimura C, Ohkubo S, Ogi K, Hosoya M, Itoh Y, Onda H, Miyata A, Jiang L, Dahl RR \& Stibbs HH 1990 A novel peptide which stimulates adenylate cyclase: molecular cloning and characterization of the ovine and human cDNAs. Biochemical and Biophysical Research Communications 166 81-89.

Ko C \& Park-Sarge OK 2000 Progesterone receptor activation mediates LH-induced type-I pituitary adenylate cyclase activating polypeptide receptor $(\mathrm{PAC}(1))$ gene expression in rat granulosa cells. Biochemical and Biophysical Research Communications 277 270-279. 
Ko C, Gieske MC, Al Alem L, Hahn Y, Su W, Gong MC, Iglarz M \& Koo Y 2006 Endothelin-2 in ovarian follicle rupture. Endocrinology 147 1770-1779.

Koh PO, Kwak SD, Kang SS, Cho GJ, Chun SY, Kwon HB \& Choi WS 2000 Expression of pituitary adenylate cyclase activating polypeptide (PACAP) and PACAP type I A receptor mRNAs in granulosa cells of preovulatory follicles of the rat ovary. Molecular Reproduction and Development 55 379-386.

Lee J, Park HJ, Choi HS, Kwon HB, Arimura A, Lee BJ, Choi WS \& Chun SY 1999 Gonadotropin stimulation of pituitary adenylate cyclase-activating polypeptide (PACAP) messenger ribonucleic acid in the rat ovary and the role of PACAP as a follicle survival factor. Endocrinology 140 818-826.

Lowry OH, Rosebrough NJ, Farr AL \& Randall RJ 1951 Protein measurement with the Folin phenol reagent. Journal of Biological Chemistry $193265-275$.

Lutz EM, Sheward WJ, West KM, Morrow JA, Fink G \& Harmar AJ 1993 The VIP2 receptor: molecular characterisation of a cDNA encoding a novel receptor for vasoactive intestinal peptide. FEBS Letters 334 3-8.

McGuinness OM, Moreton RB, Johnson MH \& Berridge MJ 1996 A direct measurement of increased divalent cation influx in fertilised mouse oocytes. Development 122 2199-2206.

Miyata A, Arimura A, Dahl RR, Minamino N, Uehara A, Jiang L, Culler MD \& Coy DH 1989 Isolation of a novel 38 residue-hypothalamic polypeptide which stimulates adenylate cyclase in pituitary cells. Biochemical and Biophysical Research Communications 164 567-574.

Paniccia R, Riccioni T, Zani BM, Zigrino P, Scotlandi K \& Teti A 1995 Calcitonin down-regulates immediate cell signals induced in human osteoclast-like cells by the bone sialoprotein-IIA fragment through a postintegrin receptor mechanism. Endocrinology 136 1177-1186.

Park HJ, Lee J, Wang L, Park JH, Kwon HB, Arimura A \& Chun SY 2000 Stage-specific expression of pituitary adenylate cyclase-activating polypeptide type I receptor messenger ribonucleic acid during ovarian follicle development in the rat. Endocrinology 141 702-709.
Pesce M, Canipari R, Ferri JL, Siracusa G \& De Felici M 1996 Pituitary adenylate cyclase-activating polypeptide (PACAP) stimulates adenylate cyclase and promotes proliferation of mouse primordial germ cells. Development 122 215-221.

Quinn P, Barros C \& Whittingham DG 1982 Preservation of hamster oocytes to assay the fertilizing capacity of human spermatozoa. Journal of Reproduction and Fertility 66 161-168.

Redmer DA \& Reynolds LP 1996 Angiogenesis in the ovary. Reviews of Reproduction 1 182-192.

Skinner MK 2005 Regulation of primordial follicle assembly and development. Human Reproduction Update 11 461-471.

Spengler D, Waeber C, Pantaloni C, Holsboer F, Bockaert J, Seeburg PH \& Journot L 1993 Differential signal transduction by five splice variants of the PACAP receptor. Nature 365 170-175.

Steiner AL, Parker CW \& Kipnis DM 1972 Radioimmunoassays of cyclic nucleotides. Journal of Biological Chemistry 2471106.

Van Blerkom J 2000 Intrafollicular influences on human oocyte developmental competence: perifollicular vascularity, oocyte metabolism and mitochondrial function. Human Reproduction 2 173-188.

Zhong Y \& Kasson BG 1994 Pituitary adenylate cyclase-activating polypeptide stimulates steroidogenesis and adenosine $3^{\prime}, 5^{\prime}$-monophosphate accumulation in cultured rat granulosa cells. Endocrinology 135 207-213.

Received in final form 14 June 2006

Accepted 17 July 2006

Made available online as an Accepted Preprint 11 August 2006 